\title{
Investigation of $\mathrm{Ba}_{2-x} \mathrm{Sr}_{x} \mathrm{TiO}_{4}$ : Structural aspects and dielectric properties
}

\author{
VISHNU SHANKER, TOKEER AHMAD and ASHOK K GANGULI* \\ Department of Chemistry, Indian Institute of Technology, New Delhi 110 016, India
}

MS received 9 June 2004; revised 13 August 2004

\begin{abstract}
Investigation of solid solution of barium-strontium orthotitanates of the type, $\mathrm{Ba}_{2-x} \mathrm{Sr}_{x} \mathrm{TiO}_{4}$ $(0 \leq x \leq 2)$, show that pure phases exist only for the end members, $\mathrm{Ba}_{2} \mathrm{TiO}_{4}$ and $\mathrm{Sr}_{2} \mathrm{TiO}_{4}$, crystallizing in the $\beta$ $\mathrm{K}_{2} \mathrm{SO}_{4}$ and $\mathrm{K}_{2} \mathrm{NiF}_{4}$ structures, respectively. The intermediate compositions (till $x \leq 1$ ) lead to a biphasic mixture of two $\mathrm{Ba}_{2} \mathrm{TiO}_{4}$-type phases (probably through a spinodal decomposition) with decreasing lattice parameters, indicating $\mathrm{Sr}$-substitution in both the phases. For $x>1, \mathrm{Sr}_{2} \mathrm{TiO}_{4}$ along with a secondary phase is obtained. The dielectric constant and dielectric loss were found to decrease with $\mathrm{Sr}$ substitution till the nominal composition of $x=1$. However, pure $\mathrm{Sr}_{2} \mathrm{TiO}_{4}$ shows higher dielectric constant compared to the solid solution composition. $\mathrm{Sr}_{2} \mathrm{TiO}_{4}$ shows very high temperature stability of the dielectric constant.
\end{abstract}

Keywords. Ceramics; solid solution; dielectric properties; electron microscopy.

\section{Introduction}

In the $\mathrm{A}_{2} \mathrm{BO}_{4}$ type of oxides, $\beta-\mathrm{K}_{2} \mathrm{SO}_{4}$ and $\mathrm{K}_{2} \mathrm{NiF}_{4}$ structures are quite popular. Oxides prefer the $\beta-\mathrm{K}_{2} \mathrm{SO}_{4}$ structure when the A-cations are much larger than the $\mathrm{B}$ cations and the $\mathrm{K}_{2} \mathrm{NiF}_{4}$ structure when the size of the Acation is smaller. Bland (1961) determined the crystal structure of $\mathrm{Ba}_{2} \mathrm{TiO}_{4}$ and observed that $\beta-\mathrm{Ba}_{2} \mathrm{TiO}_{4}$ crystallizes in a monoclinic distorted $\beta-\mathrm{K}_{2} \mathrm{SO}_{4}$ type of structure. It is now known that $\mathrm{Ba}_{2} \mathrm{TiO}_{4}$ exists in two structures (Gunter and Jameson 1984), the low temperature monoclinic phase (isostructural to $\beta-\mathrm{K}_{2} \mathrm{SO}_{4}$ ) and the high temperature orthorhombic phase, the latter being a superstructure of the monoclinic cell. Due to the unique structure of $\mathrm{Ba}_{2} \mathrm{TiO}_{4}$ (figure 1a), where isolated $\mathrm{TiO}_{4}$ tetrahedra are present compared to other titanates (including $\mathrm{Sr}_{2} \mathrm{TiO}_{4}$ ) where the $\mathrm{TiO}_{6}$ octahedron is the basic structural unit, the properties of $\mathrm{Ba}_{2} \mathrm{TiO}_{4}$ have been of interest with respect to understanding the role of $\mathrm{TiO}_{4}$ polyhedra.

Barium orthotitanate $\left(\mathrm{Ba}_{2} \mathrm{TiO}_{4}\right)$ is difficult to synthesize because it is found to be unstable. Heating $\mathrm{BaCO}_{3}$ and $\mathrm{TiO}_{2}$ at $1350^{\circ} \mathrm{C}$ temperature leads to the formation of $\mathrm{Ba}_{2} \mathrm{TiO}_{4}$ (Jonker and Kwestroo 1958). Polycrystalline $\mathrm{Ba}_{2} \mathrm{TiO}_{4}$ has also been synthesized earlier by polymeric precursor (Lee et al 1999), sol-gel (Pfaff 1992) and reverse micellar (Ahmad and Ganguli 2004) route. Marks et al (1988) synthesized microcrystalline $\mathrm{Ba}_{2} \mathrm{TiO}_{4}$, which contains a mixture of monoclinic and orthorhombic forms, by hydrolyzing a mixture of barium ethanolate and titanium tetraethanolate in water free ethanol with double distilled water. $\mathrm{Ba}_{2} \mathrm{TiO}_{4}$ is also synthesized by controlled

\footnotetext{
*Author for correspondence
}

hydrolysis of barium and titanium alkoxide precursor (Ritter et al 1986).

$\mathrm{Sr}_{2} \mathrm{TiO}_{4}$ crystallizes in the quasi-two-dimensional Ruddlesden-Popper type phase, more popularly called the $\mathrm{K}_{2} \mathrm{NiF}_{4}$ structure (Ruddlesden and Popper 1957, 1958). The structure of $\mathrm{Sr}_{2} \mathrm{TiO}_{4}$ (figure 1b) can be considered to be built of alternate layers of $\mathrm{SrO}$ and $\mathrm{SrTiO}_{3}$. There is only one report (Kwestroo and Papping 1959) of the oxides with both $\mathrm{Ba}$ and $\mathrm{Sr}$ in the A-sites $\left(\mathrm{Ba}_{0.44} \mathrm{Sr}_{1.56} \mathrm{TiO}_{4}\right.$ and $\mathrm{Ba}_{1.91} \mathrm{Sr}_{0.09} \mathrm{TiO}_{4}$ ) whose powder X-ray diffraction patterns have been reported. However, no structural details have been given and the X-ray patterns are not fully indexed. Very little work has been reported on the dielectric properties of $\mathrm{Ba}_{2} \mathrm{TiO}_{4}$ (Pfaff 1991) and $\mathrm{Sr}_{2} \mathrm{TiO}_{4}$ (Sohn et al 1996; Fennie and Rabe 2003). There is no report on dielectric properties of solid solutions of barium and strontium orthotitanates $\left(\mathrm{Ba}_{2-x} \mathrm{Sr}_{x} \mathrm{TiO}_{4}\right)$.

In this paper, we report our attempt to obtain solid solutions of the type, $\mathrm{Ba}_{2-x} \mathrm{Sr}_{x} \mathrm{TiO}_{4}(0 \leq x \leq 2)$, from solidstate (ceramic) and polymeric citrate precursor methods. We also report the dielectric properties of these phases.

\section{Experimental}

All the oxides of the type, $\mathrm{Ba}_{2-x} \mathrm{Sr}_{x} \mathrm{TiO}_{4}$, were prepared by the ceramic and polymeric precursor methods. $\mathrm{BaCO}_{3}$ (Merck, 99\%), $\mathrm{SrCO}_{3}$ (Merck, 99\%), and $\mathrm{TiO}_{2}$ (Fluka, 99\%), were used for the synthesis of the above materials by the ceramic method. In the citrate polymeric precursor method, $\mathrm{Ba}\left(\mathrm{NO}_{3}\right)_{2}$ (Merck, 99\%), $\mathrm{Sr}\left(\mathrm{NO}_{3}\right)_{2}$ (Merck, 99\%), $\mathrm{TiO}_{2}$ (Fluka, 99\%), citric acid and ethylene glycol were used for the synthesis of these materials.

In the ceramic method, stoichiometric ratio of $\mathrm{BaCO}_{3}$, $\mathrm{SrCO}_{3}$ and $\mathrm{TiO}_{2}$ were taken for the preparation of barium 
strontium orthotitanates. The mixture was thoroughly ground for $25 \mathrm{~min}$ in an agate mortar. The homogenized mixture was loaded in an alumina crucible and kept in the ceramic tube furnace for heating at $900^{\circ} \mathrm{C}$ for $15 \mathrm{~h}$. The samples were subsequently heated at $1000^{\circ} \mathrm{C}$ for $24 \mathrm{~h}$, $1050^{\circ} \mathrm{C}$ for $12 \mathrm{~h}$, and $1100^{\circ} \mathrm{C}$ for $12 \mathrm{~h}$ with intermittent grinding after each step.

The flowchart for the polymeric citrate precursor method shows all the steps involved in the synthesis and is summarized in figure 2 . The mixture of titanium tetraisopropoxide (Acros $98+\%$ ) and ethylene glycol (Qualigens, SQ grade) was stirred under nitrogen atmosphere for $10 \mathrm{~min}$ to get a clear transparent solution. Dried citric

(a)

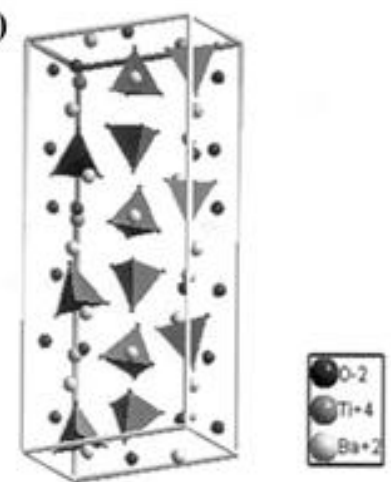

(b)

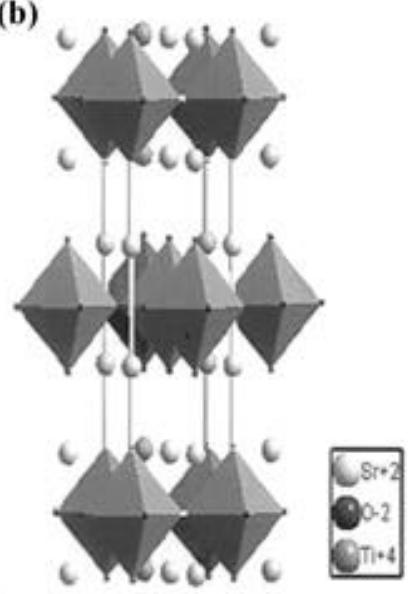

Figure 1. Structure of (a) orthorhombic $\mathrm{Ba}_{2} \mathrm{TiO}_{4}$ and (b) $\mathrm{Sr}_{2} \mathrm{TiO}_{4}$. acid (Qualigens, SQ grade, 99.5\%) was added to ethylene glycol-titanium tetraisopropoxide. The ratio of ethylene glycol: Ti-isopropoxide : citric acid was 10:1:40. A nearly white precipitate was observed immediately after adding citric acid to the solution but it disappeared after 5-6 min on stirring. Stirring was continued at room temperature till all the citric acid was dissolved and a clear solution was obtained. The starting materials in stoichiometric ratio were added to the solution as prepared as above. The contents were stirred on a magnetic stirrer for $4-5 \mathrm{~h}$ till the reactants dissolved and a clear transparent solution was obtained. This light brown solution was stirred further at $60 \pm 5^{\circ} \mathrm{C}$ for $3-4 \mathrm{~h}$. The solution was then kept in an oven at $120 \pm 5^{\circ} \mathrm{C}$ for $20 \mathrm{~h}$ to evaporate the solvent and a brown viscous resin was obtained. This resin was kept in a muffle furnace for $2 \mathrm{~h}$ at $300^{\circ} \mathrm{C}$ for charring and then cooled to room temperature. The resin turned to a black mass, which was ground to a powder in an agate mortar. This ground black mass is henceforth called a precursor. A white powder was obtained by heating this precursor at $500^{\circ} \mathrm{C}$ for $20 \mathrm{~h}$ and $800^{\circ} \mathrm{C}$ for $8 \mathrm{~h}$. The powdered sample was heated further at $950^{\circ} \mathrm{C}$ for $12 \mathrm{~h}, 1000^{\circ} \mathrm{C}$ for $13 \mathrm{~h}$ and $1100^{\circ} \mathrm{C}$ for $12 \mathrm{~h}$ to obtain the solid solution of barium strontium orthotitanates.

Powdered samples were treated with a binder (4-5 drops of $5 \%$ polyvinyl alcohol solution per $g$ of sample) and then compacted into disks at a pressure of 8 tons. These disks were sintered at $1100^{\circ} \mathrm{C}$ for $12 \mathrm{~h}$. Powder X-ray diffraction (PXRD) studies of the compounds were done after every stage of heating on a Bruker D8 Advance X-ray diffractometer with a step size of $0.05^{\circ}$ and a scan speed of $1 \mathrm{~s}$ per step in the $2 \theta$ range of $10^{\circ}-70^{\circ}$. The lattice parameters were obtained by a least-squares fit to the observed $d$-values. Energy dispersive X-ray analysis (EDX) of the powdered samples were recorded on a Cambridge LEO 4401 scanning electron microscope coupled with an Oxford ISIS EDX system. Scanning electron microscopy (SEM) was carried out on the sintered disks by using a Cambridge Stereoscan 360 electron microscope in order to study the grain size and morphology of the sample. The density of the sintered disks was obtained by the Archimedes method using $\mathrm{CCl}_{4}$. The disks were soaked in the organic medium for a sufficiently long time and the weight monitored until it became constant. For consistency, three different density measurements were carried

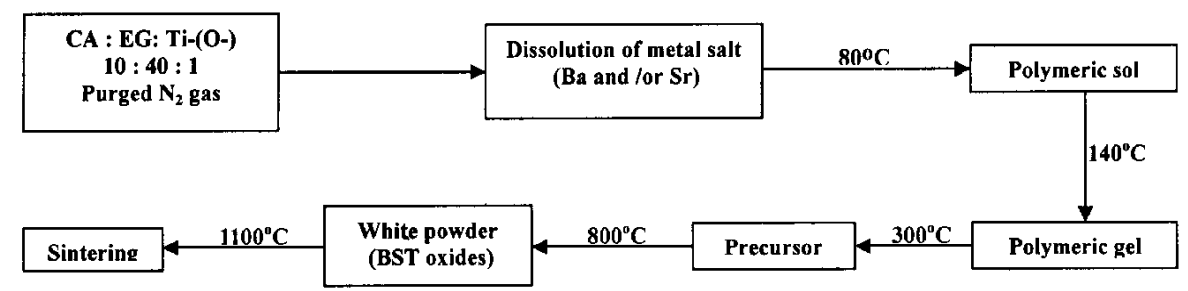

Figure 2. Flowchart showing the polymeric citrate precursor method. 
out for each sample. The density of disks sintered at $1100^{\circ} \mathrm{C}$ showed a bulk density of the order of $\sim 90 \%$.

The dielectric properties were measured on sintered disks coated with silver as electrodes using an HP 4284L LCR meter in the frequency range $50-500 \mathrm{kHz}$ at varying temperatures $\left(30-200^{\circ} \mathrm{C}\right)$.

\section{Results and discussion}

We have tried to synthesize the solid solution of barium strontium orthotitanates, with the composition, $\mathrm{Ba}_{2-x} \mathrm{Sr}_{x} \mathrm{TiO}_{4}$ $(0 \leq x \leq 2)$, by the ceramic route and polymeric citrate precursor route. However, only the end members, $\mathrm{Ba}_{2} \mathrm{TiO}_{4}$ $(x=0)$ and $\mathrm{Sr}_{2} \mathrm{TiO}_{4}(x=2)$, were obtained as pure phases by the ceramic method (figure 3 ). The X-ray pattern of the $x=0$ composition could be indexed to the orthorhombic barium orthotitanate corresponding to the pattern reported in JCPDS-75-0677 (space group $P 2{ }_{1} n b$ ). The $x=2$ com- position could be indexed to the tetragonal cell of $\mathrm{Sr}_{2} \mathrm{TiO}_{4}$ (JCPDS 39-1471, sp. group, I4/ $\mathrm{mmm}$ ). For all other compositions, we observed more than one phase in the X-ray pattern. This was found to be true for the oxides obtained by the ceramic route (figure 4) as well as the polymeric precursor route. On close examination of the reflections obtained using slow scans, we find that till $x \leq 1$, we could assign all the reflections to two phases with close relation to the orthorhombic $\mathrm{Ba}_{2} \mathrm{TiO}_{4}$ structure (corresponding to JCPDS-38-1481, space group, Pnam). Both the phases show clear shift towards lower $d$-values for the reflections, when compared to the parent $\mathrm{Ba}_{2} \mathrm{TiO}_{4}$ reflections. In figure 5, we show a small region of $2 \theta$ (containing intense reflections) obtained using a slow scan. The two phases systematically shift to lower $d$-values as the amount of 'Sr' in the nominal composition increases. Thus we believe that two $\mathrm{Ba}_{2-x} \mathrm{Sr}_{x} \mathrm{TiO}_{4}$ type of phases (with slightly different compositions) are being stabilized in the nominal composition range $x \leq 1$, and both the phases possess the
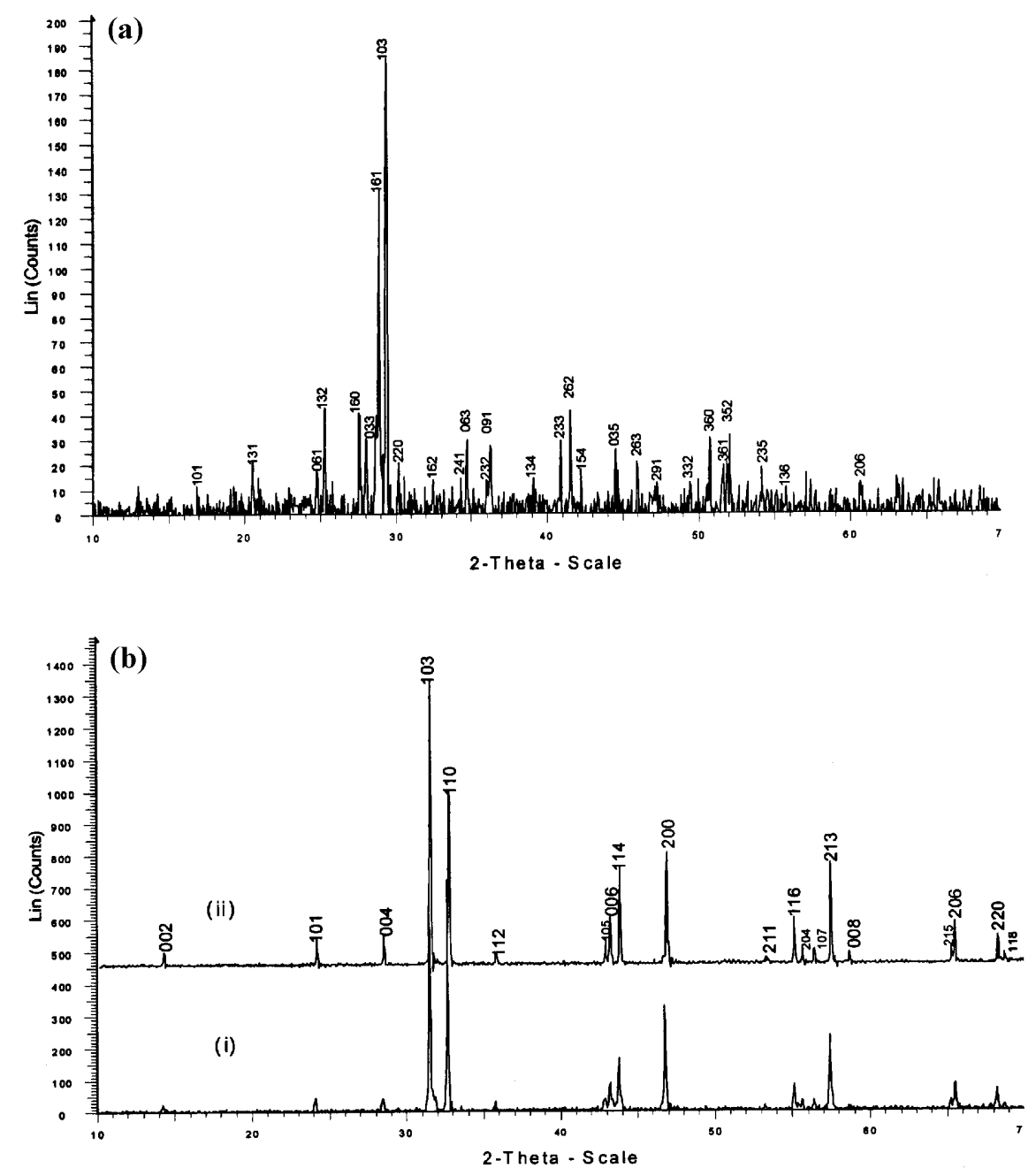

Figure 3. Powder $\mathrm{X}$-ray diffraction pattern of (a) orthorhombic $\mathrm{Ba}_{2} \mathrm{TiO}_{4}$ prepared by the ceramic method at $1050^{\circ} \mathrm{C}$ and (b) $\mathrm{Sr}_{2} \mathrm{TiO}_{4}$ prepared by (i) ceramic method and (ii) polymeric citrate precursor method. 


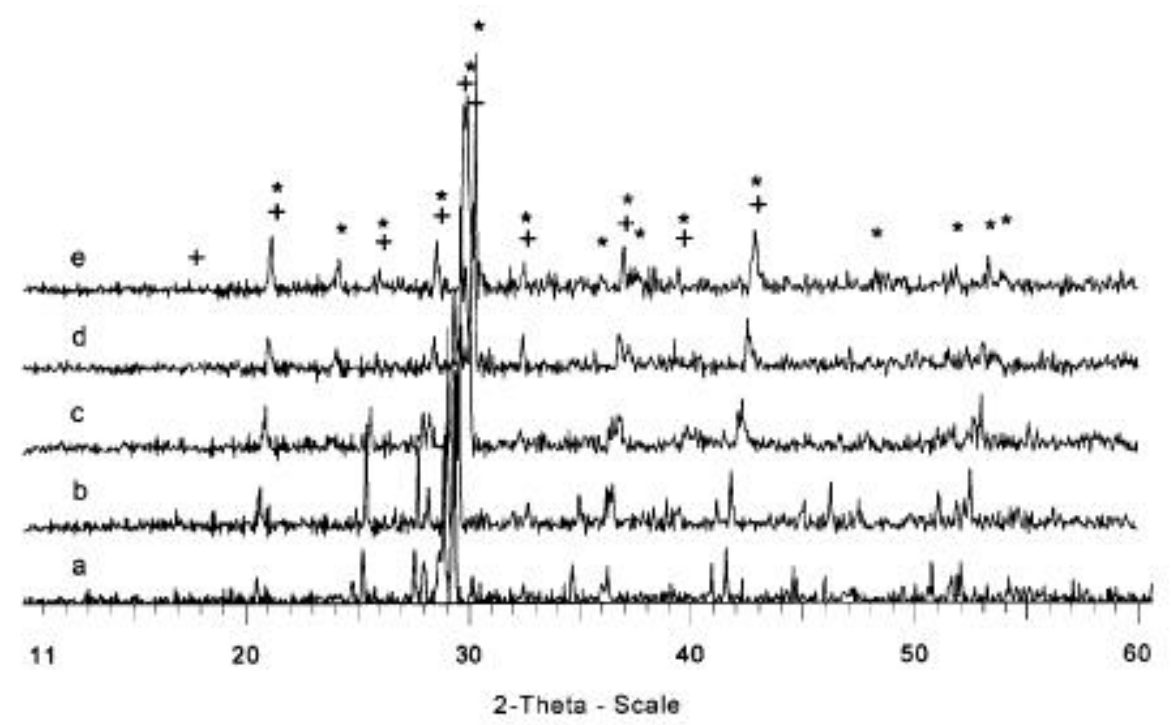

Figure 4. Powder $\mathrm{X}$-ray diffraction pattern of oxides prepared by the ceramic method at $1100^{\circ} \mathrm{C}$ with nominal composition: a. $\mathrm{Ba}_{2} \mathrm{TiO}_{4}$, b. $\mathrm{Ba}_{1.75} \mathrm{Sr}_{0.25} \mathrm{TiO}_{4}$, c. $\mathrm{Ba}_{1.50} \mathrm{Sr}_{0.50} \mathrm{TiO}_{4}$, d. $\mathrm{Ba}_{1 \cdot 25} \mathrm{Sr}_{0.75} \mathrm{TiO}_{4}$ and e. $\mathrm{BaSrTiO}_{4}$. The ortho-I (*) and ortho-II (+) phases are indicated.

ortho- $\mathrm{Ba}_{2} \mathrm{TiO}_{4}$ structure. The coexistence of two phases with slightly different lattice parameter indicates the formation of the phases by spinodal decomposition (Ramanarayan and Abinandanan 2003). We could index one phase clearly and we find a systematic decrease in the lattice parameters (table 1). For $x=0 \cdot 5$, we have indexed the two phases of $\mathrm{Ba} / \mathrm{Sr}$ solid solution. The lattice parameter of one phase is ' $a$ ' $=7 \cdot 584(8),{ }^{\prime} b$ ' $=10 \cdot 41(1)$ and ' $c$ ' $=6 \cdot 052(6)$ and another phase is ' $a$ ' $=7 \cdot 542(6), ' b$ ' $=10 \cdot 37(1)$ and ' $c$ ' = 6.032(5). Using the lattice parameters of $\mathrm{Ba}_{2} \mathrm{TiO}_{4}$ and that of the reported $\mathrm{Ba}_{0.56} \mathrm{Sr}_{1.44} \mathrm{TiO}_{4}$ (JCPDS-13-0269), we could obtain the approximate stoichiometries (using Vegard's Law) of the above two orthorhombic phases to be close to $\mathrm{Ba}_{1.64} \mathrm{Sr}_{0.36} \mathrm{TiO}_{4}$ and $\mathrm{Ba}_{1.45} \mathrm{Sr}_{0.55} \mathrm{TiO}_{4}$. These values are close to the nominal composition of $\mathrm{Ba}_{1.5} \mathrm{Sr}_{0.5} \mathrm{TiO}_{4}$. For the nominal compositions with $x \geq 1$, we find predominantly the $\mathrm{Sr}_{2} \mathrm{TiO}_{4}$ phase along with a secondary phase that appear close to the reported XRD pattern of $\mathrm{Ba}_{0.56}$ $\mathrm{Sr}_{1.44} \mathrm{TiO}_{4}$ (JCPDS-13-0269), which has a orthorhombic structure. The X-ray pattern of $x=1.25$ and $x=1.50$ compositions were indexed based on two phases, $\mathrm{Sr}_{2} \mathrm{TiO}_{4}$ and $\mathrm{Ba}_{0.56} \mathrm{Sr}_{1.44} \mathrm{TiO}_{4}$. However, the reported pattern of $\mathrm{Ba}_{0.56}$ $\mathrm{Sr}_{1.44} \mathrm{TiO}_{4}$ considered for the indexing of the above pattern does not appear to be well characterized. There are several reflections, which have not been indexed in the JCPDS report (13-0269). The pure $\mathrm{Ba}_{2} \mathrm{TiO}_{4}$ obtained by us crystallizes in the orthorhombic structure. Lee et al (1999) reported that barium orthotitanate exists in two forms, a monoclinic low temperature $\left(710^{\circ} \mathrm{C}\right)$ phase and a high temperature $\left(1200^{\circ} \mathrm{C}\right)$ orthorhombic phase. The high temperature orthorhombic phase is reported (Lee et al 1999) to be stabilized by adding $3 \%, 6 \%$ and $10 \%$ of stabilizer $\mathrm{MgO}$. Note that in our synthesis we could obtain pure

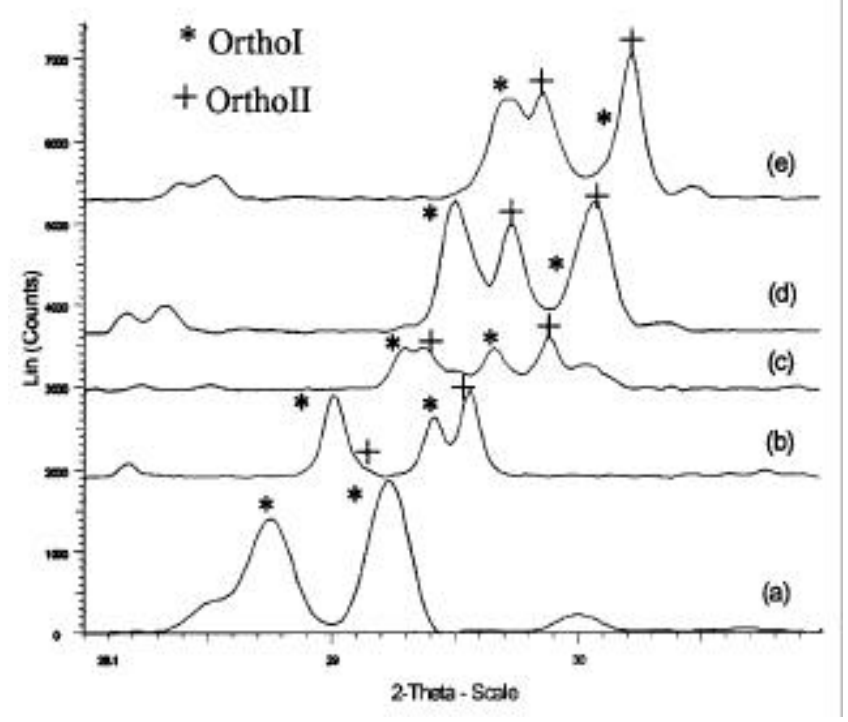

Figure 5. Powder X-ray diffraction pattern of a small range of $2 \theta$ containing the most intense peaks with nominal compositions of (a) $\mathrm{Ba}_{2} \mathrm{TiO}_{4}$, (b) $\mathrm{Ba}_{1.75} \mathrm{Sr}_{0.25} \mathrm{TiO}_{4}$, (c) $\mathrm{Ba}_{1.50} \mathrm{Sr}_{0.50} \mathrm{TiO}_{4}$, (d) $\mathrm{Ba}_{1 \cdot 25} \mathrm{Sr}_{0.75} \mathrm{TiO}_{4}$ and (e) $\mathrm{BaSrTiO}_{4}$.

$\mathrm{Ba}_{2} \mathrm{TiO}_{4}$ (orthorhombic) by the ceramic route. However, the polymeric precursor route yielded a mixture of orthorhombic and monoclinic phases.

$\mathrm{Ba}_{2} \mathrm{TiO}_{4}$ was found to decompose when exposed to air at ambient temperature (Jonker and Kwestroo 1958). Note that we also have found that disks of $\mathrm{Ba}_{2} \mathrm{TiO}_{4}$ when sintered at higher temperature of 1100 and $1200^{\circ} \mathrm{C}$, were found to crumble on cooling the disk to room temperature. The X-ray diffraction pattern of the above powder shows the formation of decomposed products like $\mathrm{BaTiO}_{3}, \mathrm{BaCO}_{3}$ 
Table 1. Lattice parameters and dielectric properties of oxides, $\mathrm{Ba}_{2-x} \mathrm{Sr}_{x} \mathrm{TiO}_{4}(0 \leq x \leq 2)$.

\begin{tabular}{|c|c|c|c|c|}
\hline \multirow[b]{2}{*}{ Composition } & \multirow[b]{2}{*}{ Method of preparation } & \multirow[b]{2}{*}{ Lattice parameter } & \multicolumn{2}{|c|}{ Dielectric properties } \\
\hline & & & $\varepsilon$ & $D$ \\
\hline $\mathrm{Ba}_{2} \mathrm{TiO}_{4}$ & Citrate method & $\begin{array}{l}\text { Forming mixture of } \\
\text { monoclinic }+ \text { orthorhombic }\end{array}$ & - & - \\
\hline $\mathrm{Ba}_{2} \mathrm{TiO}_{4}$ & Ceramic method & $\begin{array}{l}a^{\prime}=6 \cdot 110(1) \\
b^{\prime} b=22 \cdot 919(9) \\
c^{\prime}=10 \cdot 538(2)\end{array}$ & \multicolumn{2}{|c|}{ disk crumbled } \\
\hline $\mathrm{Ba}_{1 \cdot 75} \mathrm{Sr}_{0 \cdot 25} \mathrm{TiO}_{4}$ & Citrate method & $\begin{array}{l}a^{\prime}=7 \cdot 619(1) \\
b^{\prime} b=10 \cdot 482(2) \\
c^{\prime}=6 \cdot 083(1)\end{array}$ & 35 & $0 \cdot 346$ \\
\hline $\mathrm{Ba}_{1.50} \mathrm{Sr}_{0.50} \mathrm{TiO}_{4}$ & Citrate method & $\begin{array}{l}{ }^{\prime}{ }^{\prime}=7 \cdot 566(6) \\
b^{\prime}=10 \cdot 413(9) \\
c^{\prime}=6 \cdot 063(7)\end{array}$ & 28 & $0 \cdot 068$ \\
\hline $\mathrm{Ba}_{1 \cdot 25} \mathrm{Sr}_{0.75} \mathrm{TiO}_{4}$ & Citrate method & $\begin{array}{l}{ }^{\prime}{ }^{\prime}=7 \cdot 491(6) \\
b^{\prime}=10 \cdot 270(1) \\
c^{\prime}{ }^{\prime}=6 \cdot 015(5)\end{array}$ & 18 & $0 \cdot 046$ \\
\hline $\mathrm{Ba}_{1 \cdot 00} \mathrm{Sr}_{1 \cdot 00} \mathrm{TiO}_{4}$ & Citrate method & $\begin{array}{l}{ }^{\prime} a '=7 \cdot 413(7) \\
{ }^{\prime} b=10 \cdot 222(8) \\
c^{\prime} c^{\prime}=5 \cdot 944(5)\end{array}$ & 15 & $0 \cdot 022$ \\
\hline $\mathrm{Ba}_{1 \cdot 00} \mathrm{Sr}_{1 \cdot 00} \mathrm{TiO}_{4}$ & Ceramic method & $\begin{array}{l}{ }^{\prime} a '=7 \cdot 385(9) \\
b^{\prime}=10 \cdot 19(1) \\
c^{\prime} c=5 \cdot 975(8)\end{array}$ & 21 & 0.054 \\
\hline $\mathrm{Sr}_{2} \mathrm{TiO}_{4}$ & Citrate method & $\begin{array}{l}a^{\prime}=3 \cdot 8796(4) \\
c^{\prime}=12 \cdot 578(1)\end{array}$ & 27 & $0 \cdot 003$ \\
\hline $\mathrm{Sr}_{2} \mathrm{TiO}_{4}$ & Ceramic method & $\begin{array}{l}{ }^{\prime} a '=3 \cdot 8790(5) \\
c^{\prime}=12 \cdot 562(2)\end{array}$ & 20 & 0.0094 \\
\hline
\end{tabular}

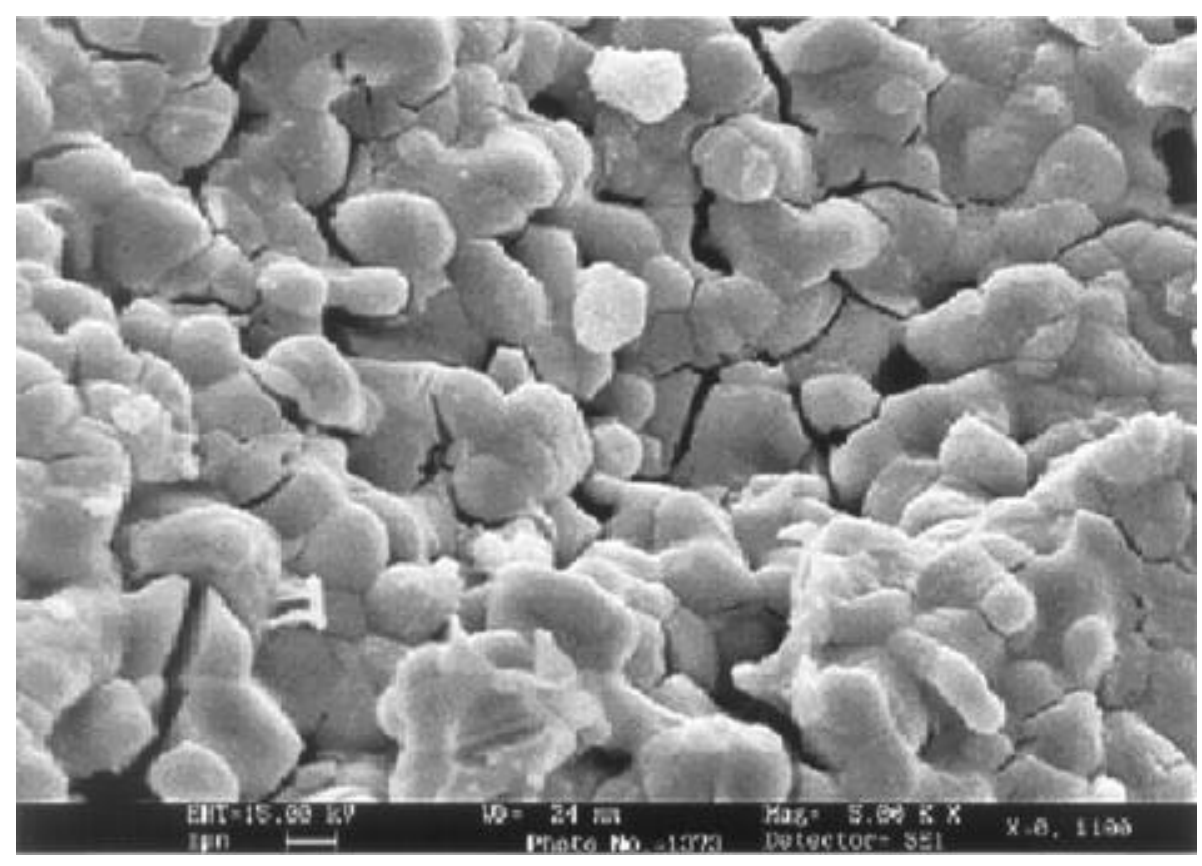

Figure 6. Scanning electron micrograph of $\mathrm{Ba}_{2} \mathrm{TiO}_{4}$ prepared by ceramic method sintered at $1100^{\circ} \mathrm{C}$. 


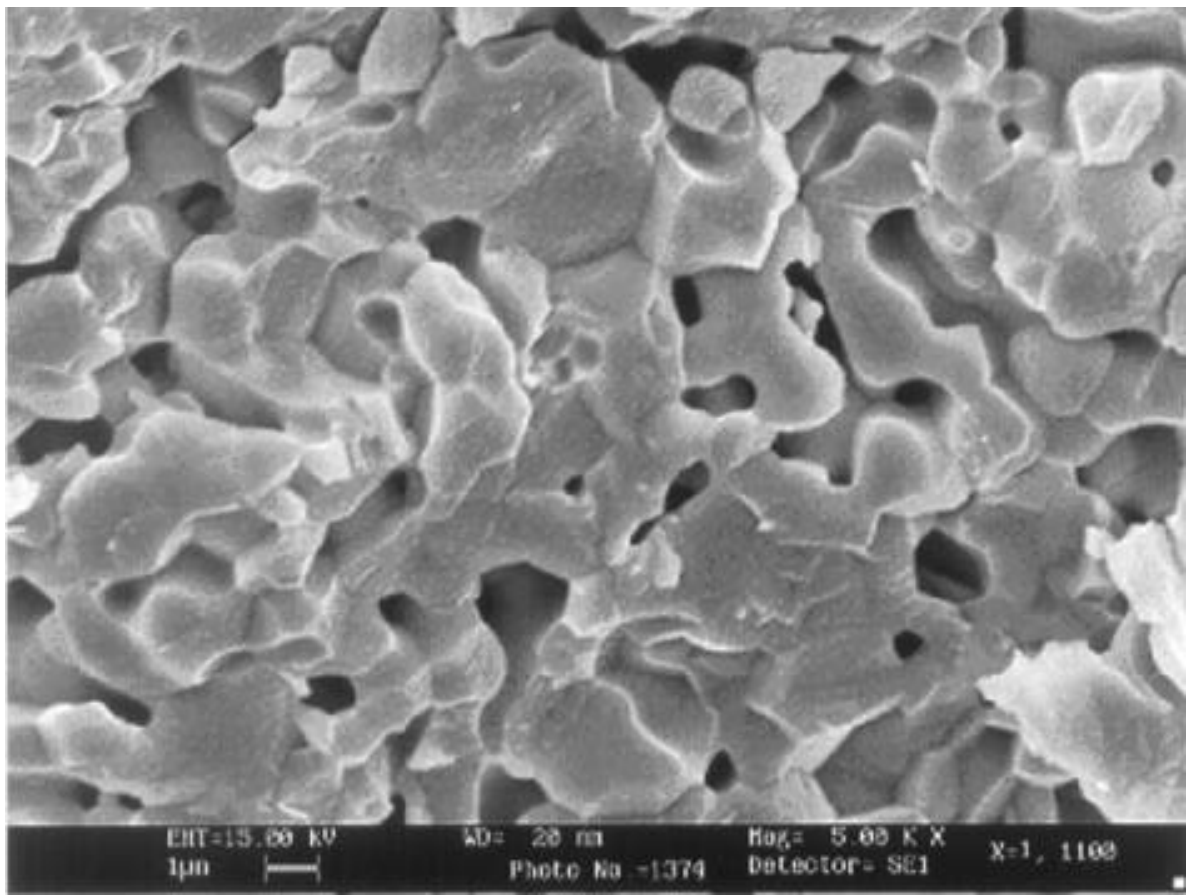

Figure 7. Scanning electron micrograph of $\mathrm{BaSrTiO}_{4}$ prepared by ceramic method and sintered at $1100^{\circ} \mathrm{C}$.

and $\mathrm{TiO}_{2} \cdot \mathrm{Ba}_{2} \mathrm{TiO}_{4}$ (as obtained by the ceramic route) without further sintering was also found to decompose to $\mathrm{BaTiO}_{3}, \mathrm{BaCO}_{3}$ and $\mathrm{TiO}_{2}$ (after 15 days) and after a long time (2 months) to $\mathrm{BaCO}_{3}$ and $\mathrm{TiO}_{2}$. We conclude that $\mathrm{Ba}_{2} \mathrm{TiO}_{4}$ is highly unstable in air and hence the calcined powder was kept in a desiccator under vacuum.

Energy dispersive X-ray analyses were carried out on the compositions with $x=0,1$ and 2 . The following stoichiometric compositions, $\mathrm{Ba}_{2.09} \mathrm{Ti}_{0.82} \mathrm{O}_{4}, \mathrm{Ba}_{0.98} \mathrm{Sr}_{1 \cdot 16} \mathrm{Ti}_{0.82} \mathrm{O}_{4}$, and $\mathrm{Sr}_{1.96} \mathrm{Ti}_{1.05} \mathrm{O}_{4}$, respectively were obtained which are very close to the nominal compositions.

Scanning electron micrographs (SEM) of few compositions prepared by the ceramic and polymeric citrate precursor methods were recorded. The SEM studies on the compositions $x=0,1$ and 2 prepared by ceramic method show larger grain size than obtained by citrate method. The grain size of $\mathrm{Ba}_{2} \mathrm{TiO}_{4}$ prepared by the ceramic method was found to be $1-2 \mu \mathrm{m}$ (figure 6 ). The grain size increases on substitution of $\mathrm{Sr}$ at the Ba-site. The grain size of $\mathrm{BaSrTiO}_{4}$ prepared by the ceramic method was found to be $1 \cdot 5-3 \mu \mathrm{m}$ (figure 7 ). The micrographs show that the grain boundaries are not well defined and the grains are coalescing.

Dielectric measurement of all the compositions was carried out on disks sintered at $1100^{\circ} \mathrm{C}$ in the temperature range $35-250^{\circ} \mathrm{C}$. The dielectric measurement of $\mathrm{Ba}_{2} \mathrm{TiO}_{4}$ was not possible since the sintered disk crumbled to powder. It is observed that both the dielectric constant and dielectric loss decrease as $\mathrm{Sr}$-substitution increases in case of the samples prepared by the polymeric citrate method (table 1). It has to be noted here that the dielectric con-
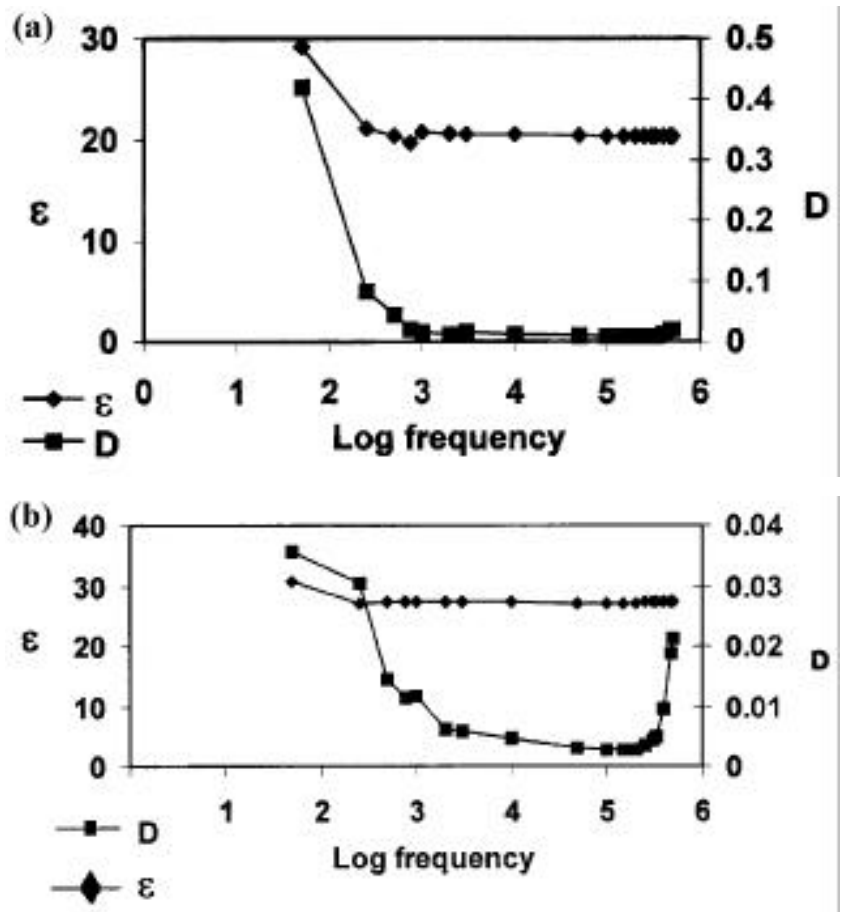

Figure 8. Variation of the dielectric constant $(\varepsilon)$ and dielectric loss $(D)$ with frequency for $\mathrm{Sr}_{2} \mathrm{TiO}_{4}$ prepared by (a) ceramic route and (b) polymeric citrate precursor route.

stant at room temperature for the composition with $x=1$ $\left(\mathrm{BaSrTiO}_{4}\right)$ gives a higher value for the sample prepared by the ceramic method $(\sim 21$ at $100 \mathrm{kHz})$ than those prepared by the citrate method $(\sim 15$ at $100 \mathrm{kHz})$. This is probably due to the large grain size and higher density as 


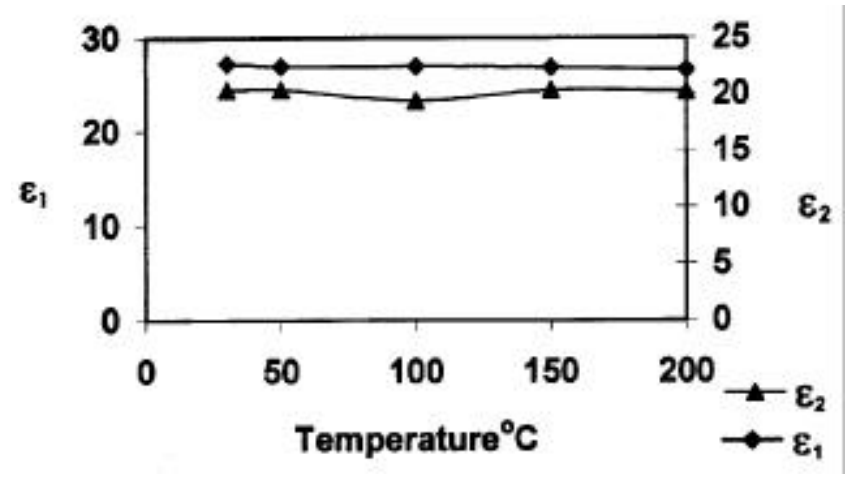

Figure 9. Comparison of the dielectric constant with temperature at $100 \mathrm{kHz}$ for $\mathrm{Sr}_{2} \mathrm{TiO}_{4}$ prepared by polymeric citrate precursor route $\left(\varepsilon_{1}\right)$ and ceramic route $\left(\varepsilon_{2}\right)$.

observed by SEM studies where the grains are coalescing (figure 7). The dielectric constant $(\varepsilon)$ of $\mathrm{Sr}_{2} \mathrm{TiO}_{4}$ prepared by citrate method was higher $(\varepsilon=27)$ than that obtained by ceramic method $(\varepsilon=20)$ probably due to the densely packed grains in the former case as shown in SEM studies. The dielectric constant $(\varepsilon)$ was stable in the entire range of frequency irrespective of the preparative method (figures $8 \mathrm{a}$ and $\mathrm{b}$ ). The dielectric loss $(D)$ shows a stable value for frequencies $>1 \mathrm{kHz}$ (figure $8 \mathrm{a}$ ). However, a dielectric loss peak was observed at higher frequencies (>500 kHz) in the oxide obtained by the citrate method (figure $8 \mathrm{~b}$ ). The dielectric constant was highly stable in the range of temperature $\left(35-200^{\circ} \mathrm{C}\right)$ for $\mathrm{Sr}_{2} \mathrm{TiO}_{4}$ prepared by either method (ceramic and citrate) and is shown in figure 9 . Note that the dielectric constant of $\sim 35$ was reported earlier (Sohn et al 1996) at $54 \mathrm{kHz}$ for $\mathrm{Sr}_{2} \mathrm{TiO}_{4}$ obtained by sintering at $1650^{\circ} \mathrm{C}$, which probably leads to a much higher density. This could explain the lower dielectric constant $(\varepsilon=20)$ in $\mathrm{Sr}_{2} \mathrm{TiO}_{4}\left(\right.$ sintered at $\left.1100^{\circ} \mathrm{C}\right)$ in our study.

\section{Conclusions}

Solid solution of the type, $\mathrm{Ba}_{2-x} \mathrm{Sr}_{x} \mathrm{TiO}_{4}$ could be obtained for composition with $0 \leq x \leq 1$. However, two such phases coexist and monophasic oxides could be obtained only for the end members. The presence of two phases with compositional variation in equilibrium indicates the formation of these phases through a spinodal decomposition. Thus the Ba-rich region (crystallizing in the $\beta-\mathrm{K}_{2} \mathrm{SO}_{4}$ structure) allows for substitution of smaller $\mathrm{Sr}$ ion keeping the structure intact. On the other hand there is practically no solubility of $\mathrm{Ba}$ in $\mathrm{Sr}_{2} \mathrm{TiO}_{4}\left(\mathrm{~K}_{2} \mathrm{NiF}_{4}\right.$ structure $)$. Stable $\mathrm{Sr}_{2} \mathrm{TiO}_{4}$ could be obtained by either method. The dielectric constant and dielectric loss of the oxides were found to decrease with Sr-substitution in the range $x \leq 1 . \mathrm{Ba}_{2} \mathrm{TiO}_{4}$ was found to decompose when sintered and cooled.

\section{References}

Ahmad T and Ganguli A K 2004 J. Mater. Res. (in print) Bland J A 1961 Acta Crystallogr. 14875

Fennie C J and Rabe K M 2003 Phys. Rev. B68 184111

Gunter J R and Jameson G B 1984 Acta Crystallogr. C40 207

Jonker G H and Kwestroo W 1958 J. Am. Ceram. Soc. 41390

Kwestroo W and Papping H A M 1959 J. Am. Ceram. Soc. 42 292

Lee S J, Biegalski M D and Kriven W M 1999 J. Mater. Res. 143001

Marks O, Gunter J R and Hofer F 1988 React. Solids 6217

Pfaff G 1991 J. Mater. Sci. Lett. 101059

Pfaff G 1992 J. Mater. Chem. 2591

Ramanarayan H and Abinandanan T A 2003 Physica A318 213

Ritter J J, Roth R S and Blendell J E 1986 J. Am. Ceram. Soc. 69155

Ruddlesden S N and Popper P 1957 Acta Crystallogr. 10538

Ruddlesden S N and Popper P 1958 Acta Crystallogr. 1154

Sohn J H, Inaguma Y, Itoh M and Nakamura T 1996 Mater. Sci. Eng. B41 50 